\title{
THE CONCEPT OF HARMONY IN CHINESE CULTURE AND THE CHINESE SUSTAINABLE DEVELOPMENT
}

\author{
Katarzyna MAZUR-KAJTA \\ Politechnika Opolska; k.mazur-kajta@po.edu.pl, ORCID: 0000-0002-4822-9328
}

\begin{abstract}
Purpose: The purpose of the paper is to illustrate the broad cultural context affecting the economy and the consequences of economic development in the natural environment and social development.

Design/methodology/approach: The method chosen was the analysis of literature on the subject in Polish, English and Chinese language.

Findings: The article presents the ancient Chinese point of view on the idea of harmony between a human being and the nature, as well as the reasons behind the origin of the People's Republic of China's direction towards sustainable development. It is influenced by both the imbalance between economic growth and environmental degradation, as well as social challenges.
\end{abstract}

Originality/value: The paper shows and explains the main problems faced by the economic development, as well as the roots of socio-economic behavior on a cultural basis.

Keywords: harmony, People's Republic of China, economic culture, sustainable development.

Category of the paper: Research paper.

\section{Introduction}

In Chinese culture, the concept of harmony is extremely important and can be described as having its own character - the Chinese character. It means that it could only be understood in the Chinese way - not necessarily compatible with the European or Western concept. This concept is most often described in the literature of the subject as related to the Confucian philosophy (which links both of the assumptions of doctrine of the mean and the great harmony), but, in reality, it has much earlier beginnings. The records concerning this concept can be found in one of the oldest classical texts - Book of Changes, in which it is described as a way to dao, which was also an inspiration for Taoism. Harmony could also be understood, among others, as a symbol (in the form of Chinese characters, taiji - yinyang, the crane and even the $c r a b$ ), the way of achieving physical and mental health (among others through qigong 
and taijiquan, Chinese medicine practice and Chinese cuisine), determinants of aesthetics, reference to Buddhist philosophy idea of no disturbance between phenomena, one of the key values of a socialist society and as a sustainable development. The genesis of PRC's orientation towards sustainable development derives from the contemporary discord between human activities related to economic development and its impact on the natural environment, as well as caring for its biodiversity for subsequent generations. Although the achievement of harmony with nature is not the only purpose China aims at in terms of sustainable development (it has many social challenges ahead as well), it was already a long time ago when the category of harmony, understood in "Chinese" manner, was, in the first instance, associated with the surrounding ecosystem. Taking the above into consideration, this article presents the ancient Chinese point of view on the idea of harmony between the human and the nature, as well as reasons which made PRC go towards sustainable development.

\section{Chinese genesis of sustainable development - an aspect of harmony with nature}

China has been and continues to be an agrarian community. Despite the fact that the agricultural area covers only $10 \%$ of the country's land, agriculture is the livelihood of over $70 \%$ of the population. In relation to that, it could be said that man has tried to cooperate with nature in this area for quite a long time. The man turned wastelands into lands that could be used for agriculture in accordance with passing seasons, i.e. in line with the cycle established by forces of nature. The solar calendar, which is based on the position of the Earth in relation to the Sun, has been created and it emphasizes the importance of sunrises and sunsets. Observing the change in the position of the Sun, the year has been divided into 24 seasons, which reflect alterations in celestial phenomena, climate, precipitation and the relationship between them. The seasons arrange the crop year, so the lives of farmers, in division into two groups (中国人的 20 个传统节日, 2011, p. 4): the major seasons and the minor seasons, which are detailed as for the days of their beginning and end. For example, great heats last from the $22^{\text {nd }}$ to the $24^{\text {th }}$ of July, whereas great frosts last from the $20^{\text {th }}$ to the 21 st of January etc. The solar calendar worked well on farms engaged in agriculture. The lunar calendar was also created and it is based on the movement of the Moon, emphasizing the importance of the full moon and the new moon. According to the observation of this celestial body, it was established, among others, that a month consists of 30 days (give or take one day), starting from the new moon, and the distinction has been made - helpful in organizing social life - into holidays that are considered traditional in China, for example the Lantern Festival - the first full moon of the new year (the $15^{\text {th }}$ day of the first month), the Mid-Autumn Festival - the full moon of the $8^{\text {th }}$ month, the Dragon Boat Festival - the $5^{\text {th }}$ day of the $5^{\text {th }}$ month, the Double Ninth Festival 
(the Chongyang Festival) - the $9^{\text {th }}$ day of the $9^{\text {th }}$ month etc. To limit the confusion associated with the occurrence of two calendars, the two above were combined, by adding an additional month, to create the lunisolar calendar, which is also called the yin-yang calendar. As Natalia Brede points out, harmony with nature can be considered on two levels: in accordance with the seasons, which are designated by the cycle of the Earth around the Sun, and in compliance with the cycles of the Moon - counting time from the new moon to the full moon and again to the new moon (Brede).

On the other hand, nongli - agricultural calendar, which is also called the traditional Chinese calendar, contains both the insights resulting from the observation of the Sun and the Moon, as well as numerous tips on agricultural activity and other, for instance, concerning some of the ailments and ways of preventing them. According to this calendar, life in rural areas was in harmony with nature. In this calendar, not only annual work and social life, but also division of activities on individual days was planned (Eberhard, 2001, p. 102; Kajdański, 2005, p. 106). Nongli calendars are printed in China to this day and are still being used both at work in rural areas and by inhabitants of cities - mostly due to the fact that they are a sort of compendium of knowledge about what is worth doing on a given day and what should be avoided. Pieces of advice included in the calendar are, for example, related to important events, such as weddings, funerals or decisions concerning moving to a new house, planning travels, starting a business or treatment. In case when the date of the planned funeral or opening a business falls on an unfavorable day, then people who live in accordance with nature (calendar) move the planned celebration to another, more favorable day. The number of favorable and unfavorable days is limited and their precise determination, apart from the calendar, is possible through consultation with a master fengshui specialist, who designates the right moment, so that harmony and nature remain balanced. Man is not only a part of nature - by adapting to its rhythm - but he also has an influence on its transition. Prescinding from rather idealized Taoist and Confucian vision of a perfectly harmonious relationship between a human and nature, since ancient times, in China, man has tried to subdue and even dominate nature. According to the legends, it was the Yellow Emperor, the mythical founder of the Xia dynasty [2070-1600 BC], who divided the world into 9 regions, controlled flood and subdued rivers, so he took a fight with unfavorable natural conditions (Obringer, 2009, pp. 266-267). Any course of action taken by subsequent rulers to affect nature was interpreted by underlings as good, until they led to natural disasters, such as floods, earthquakes or droughts. Declines of the largest Chinese dynasties were closely related to extreme phenomena in nature, which caused damages. According to tradition, the Chinese believed that natural disasters were caused by the loss of the mandate of the Heavens by the one who was wielding power - the way he was ruling was inconsistent with the will of the Heavens. Maintaining harmony with nature was and still continues to be a guarantee of social contentment and, as a result, prolongation of support for the ones who wield power. Contemporary people's spectacular interference in nature, attempts of its subdual, due to, among others, historical (including political), ecological, geological, 
demographic and economic aspects, divided public opinion into supporters and opponents of those changes. Modern gigantic projects, which interfere in nature and which are called the wonders of Chinese engineering, include:

1. The Three Gorges Dam - a hydroelectric power plant on the Yangtze River that affects the change of the tilt of the Earth's axis and even extends the day by 0.06 microseconds.

2. South-North Water Transfer Project - a hydrological project that aims at transporting water from the south to the northern areas on a distance of $2400 \mathrm{~km}$ until 2050.

3. Qinghai-Tibet railway - a railway, which is located the highest in the world.

Among factors initiated by man, which have an enormous impact on the change of the natural environment, the most important one is economic development. The Chinese economy is the most dynamically developing in the world, as evidenced by the analysis of the economic situation itself, for example, the gross domestic product price index. According to the World Bank's data, in China, it was developing the most dynamically in the years: 1964-1965 (18.8\% and $16.9 \%$ respectively), $1969-1970$ (16.9\% and 19.3\%), 1978 (11.7\%), 1984-1985 (15.1\% and 13.4\%), $1987-1988(11.7 \%$ and $11.2 \%)$, then $1992-1994(14.2 \%, 13.8 \%$ and $13.1 \%)$ and $2005-2007(11.4 \%, 12.7 \%$ and $11.4 \%)$. Since 2011 , the index is no longer a two-digit number, but despite the concerns that the giant is slowing down, the pace of growth is not stable and the Chinese economy is weakening, so far, it has been on the level of over $6 \%$. In addition, when analyzing GDP fluctuations chart in the period after 2007, it seems to be oscillating visually more harmoniously around the same value, in the sense that there are fewer visible drops and sharp increases. This index is not the ideal gauge, it is sometimes questioned in terms of universality, however, economic forecasts and assessments, as well as some of the political decisions, are made on its basis. From a more global perspective, it is also worth emphasizing that, in the late 1970s, China produced almost 5\% of the global GDP, and today it is around $18 \%$, which makes PRC the second-largest producer in the world. This country, in just 30 years, has transformed itself from a third-world country into an economic power. According to Chinese declarations, China will shortly overtake the USA and the sum of added value created by EU member states, which currently generate (each separately) about $22 \%$ of the global GDP.

As in the Chinese saying: one is divided into two [ 一分为二], which may also be related to the idea of complementary yin-yang contradictions, everything has its good and bad aspects. The intensive production of goods is accompanied by superfluous exploitation of resources, mainly of the natural environment. At present, China is the biggest energy consumer and $\mathrm{CO}_{2}$ producer in the world. This country is responsible for about $1 / 4$ of $\mathrm{CO}_{2}$ and $\mathrm{SO}_{2}$ emissions, as well as $1 / 3$ of $\mathrm{NO}_{2}$ emission on our globe (Gacek). However, there are opinions saying that, in case China resigned from the $\mathrm{CO}_{2}$ emission, it would also stop its economic development. 
Taking into consideration the period from the $21^{\text {st }}$ century BC until the $17^{\text {th }}$ century AD (The Ming dynasty period), among others, there is a noticeable trend that, together with the population growth, afforestation is decreasing, whereas the number of desert areas, as well as the natural environment degradation degree, is increasing. The reference to issues strictly regarding the scientific approach to environmental pollution in China can only be made against the background of the twentieth century. It was mainly affected by the fact that the Chinese society was mostly an agricultural nation, in addition, virtually until 1912, it was subject to imperial authority (under its rule only the members of the imperial family, the military, affluent officials and the clergy, so just a small proportion of the society, had the opportunity to educate themselves). What is more, only since the implementation of the reforms by Deng Xiaoping, China opened to the world and, as a result, it became susceptible to information and requirements related to protecting the globe from unfavorable human activity. According to Edward Kajdański, only after 1992, the ten-point plan of developing an environmental protection strategy, which had been compiled at the UN conference, was introduced in China. Two years later, the environment protection program was covered in the White Paper. However, only after 1997, the pollution of the environment was included in the Criminal Code as a crime (Kajdański, 2005, p. 174). Until the late 1970s, heavy industry, which had been intensively exploiting resources and the environment, was flourishing in China.

In 1994, the State Council assumed that economic growth would allow to get rid of poverty and improve the standard of living of people, which is why it is identified with the first and necessary condition for sustainable and permanent development. Next, according to the White Paper of the Chinese Agenda 21 on China's Population, Environment and Development in the $21^{\text {st }}$ Century, the following was taken into account: limitation of excessive population, provision of medical care, high-quality education and equal opportunities (including combating illiteracy, as well as raising the level of women's education), combating poverty (especially in rural areas), social care system for the elderly and work on migration policy, as well as natural environment protection, especially affecting the conditions of human settlement (China's Population and Development in the $21^{\text {st }}$ Century; Lei Xiong, 2009, pp. 2146-2151). Eighteen years later, in 2012, through National Report on Sustainable Development, attention was drawn to, among others, issues, such as: economic restructuring and transformation of the development model (sustainable agricultural production capacity, modern service sector development, promoting mitigation of poverty effects, as well as development on a regional basis, supporting pro-ecological consumption), human development and social progress (promoting long-term sustainable development, improving employment level; establishing and improving social security system, improving the living conditions of the citizens), sustainable use of the resources (promoting energy saving and developing, economical and rational use of resources: mineral, land, water, protection of marine resources), environment protection and limiting climate change (environment pollution control, ecological protection and resources renewal, reaction to global climate changes), sustainable construction of development potential 
(increasing scientific and technological innovation abilities, improving disaster prevention abilities, as well as limitation of their effects, creation of a solid legal and regulatory system, encouraging social involvement), international cooperation (consolidation of cooperation with developing and developed countries, implementation of international conventions in the environment protection field) (中华人民共和国可持续发展国家报告). It was assumed that, in this way, China will be able to strive for modernization of the country, as well as the comprehensive development of its citizens.

Progressive urbanization, exceptionally fast economic growth, declining forest area, excessive exploitation of flora and fauna (especially the ones that are considered to have healing properties) (Obringer, 2009, pp. 266-267) have further influenced environmental problems and effects not only sensed by man, which affect not only their lifespan, but also absorbing $10 \%$ of already generated GDP (Gacek, 2005, p. 82). For example, as a result of respiratory tract diseases, which are caused, among others, by PM2.5 dust air pollution, 350-500 thousand people die prematurely every year in China (Gacek, 2005, p. 86 after 陈竺). Over the last 40 years, lung cancer has become the main cause of cancer deaths in the People's Republic of China. In Shandong province alone, between 2011 and 2013, there were nearly eight times more deaths from this disease than in the period between 1970-1974 (Fu et al.).

Among the effects resulting from excessive exploitation of the natural environment, the following could be listed:

- climate changes, which bring about, among others, an increase in air temperature by $0.5-0.8^{\circ} \mathrm{C}$, less atmospheric precipitation (according to forecasts comparing the year 2000 and 2020, the average annual temperature will increase between 1.3 and $2.1^{\circ} \mathrm{C}$ ), extreme changes in the weather, including heatwaves, which result in droughts, and which occur mainly in the north and the north-west of the country, as well as floods combined with very intense precipitation, raising of sea levels and glaciers melting, mainly in the area of Qinghai-Tibet plateau and the Tianshan mountain range - in 2007, reduction of permafrost by $21 \%$ was observed, in comparison with its state 50 years ago (中国应对气候变化国家方案);

- declining animal species population, with tigers, Bactrian camels, dolphins, gibbons and giant pandas at the lead (WWF: Urbanizacja $i$ uprzemystowienie Chin zagrazaja bioróżnorodności; Species are disappearing...);

- extinct flora - ongoing phenomenon of deforestation and desertification is observed (the forest cover rate in 2018 in China was 21.63\%), losses in flora especially concern plants that are used in Chinese medicine, demand for them continually grows, and as much as $70 \%$ of them belongs to the so-called wild resources (Chi et al. after Huang et al., 2012); 
- the ongoing erosion and degradation of the soil that already concerns over $30 \%$ of the country $\left(2,941,100 \mathrm{~km}^{2}\right)$, which, on average, loses over $10 \mathrm{~km}^{2}$ of the land annually, makes China part of the group of countries which have one of the most serious soil erosion in the world (中国水土流失面积占国土3 成 每年损失百万亩耕地);

- water shortage and its contamination - in 2018, in eight provinces of the PRC insufficient water resources were observed, whereas demand for water continually grows (Davies, Westgate). As much as $80 \%$ of China's water resources are located in the southern areas. According to the Institute of Public and Environmental Affairs, $35 \%$ of Chinese water reservoirs have good quality water, then $32 \%$ of the resources are suitable for the so-called supply, $20 \%$ only for the industrial or agricultural use, however, the remaining $13 \%$ does not meet any standards that would allow its use (Webber);

- air pollution - annual levels of PM2.5 in China are, on average, five times higher than the limit recommended by the World Health Organization (allowing $10 \mu \mathrm{g} / \mathrm{m}^{3}$ ). According to the results of research carried out under Berkeley Earth Project, only in four months of 2014, around 92\% of China's population was exposed to over $120 \mathrm{~h}$ of unhealthy air. In major cities, with Beijing in the first place, for 4 months in a year there is smog. However, it is the coal industry that is responsible for the formation of as much as $40 \%$ of PM2.5 (steel and cement producers) (Is air quality in China a social problem?).

In terms of a healthy environment and ecosystem viability, China occupies the $120^{\text {th }}$ place out of 180 analyzed by the Yale Center for Environmental Law \& Policy and the Center for International Earth Science Information Network at Columbia University's Earth Institute. This is mainly due to the Environmental Performance Index, which, for China, is 50.74 and it consists of two indexes: Environmental Health, which is calculated at 31.72, and Ecosystem Vitality, estimated at 63.42 (2018 EPI Results).

Because of the above, the need for a more harmonized relationship between man and the surrounding environment, as well as the need for sustainable development were noticed. According to the constitution of the PRC, sustainable development should use the natural resources in a way that takes into account future generations, therefore, the way which would limit consumption and pollution and, simultaneously, satisfy social needs - high efficiency. The need to achieve harmony between economic growth, social integration and environment protection has been stated.

\section{Chinese genesis of sustainable development - an aspect of social harmony}

Orientation towards sustainable development, publicizing through supporting harmony between man and nature, as well as balancing the growth in urban and rural regions, have started 
in China in 1992. It is a comparatively difficult task, because, apart from natural environment degradation, which brings about climate changes, China faces many other social challenges, which include, among others:

- social stratification, especially between the inhabitants of rural and urban areas, as well as between western, eastern and partially southern part of the country. Together with the economic growth, reduction of poverty can be noticed (China was classified, in 2017, into the group of countries with the income above average, USD 26.872 per adult on average, with $10.3 \%$ share in global wealth (Global Wealth Databook, 2017, p. 21)), which is accompanied by a rise of inequality. For instance, income inequality distribution rate (for which the maximum value is 1), Gini coefficient for China, in 2017, was 0.47 and it has rising tendencies; whereas GDP per capita in comparison with other countries of the world is no longer on the second, as in the case of GDP, but only on the $233^{\text {rd }}$ place $^{1}$;

- intensive urbanization, which brings about mass migrations of people from rural areas to cities (estimated at 900 million people) with no residence and work permit at the same time - the problem that connects to the hukou registration of residence system, which results in legal impediments in free movement of workers, and which affects regional inequalities. The problem has escalated to such extent that, for instance, in Beijing, in 2016, $80 \%$ of construction workers were people who were called migrant rural workers. Apart from the construction sector, they work for sectors related to: protection of property, care over households (performing services, such as: cleaning, preparing meals, caring for dependent people) and works related to urban greenery, as well as postal services (couriers). Labor migration bring about further problems related to a phenomenon which could be called (as an analogy to the term Euro-orphan) Sino-orphan, because, in the first migration waves, only parents migrate, which means that they leave their children with their relatives;

- emerging belief that the value of man, and therefore his social position, is mainly determined by his wealth (Góralczyk, 2018, pp. 249-252), results not only in living for show and excessive consumerism of luxury goods, lack of "higher quality" value or the so-called "other space", but also in unethical behaviors that could negatively affect human life by distribution of products harmful to health (including food, medicines, toys, clothing) to generate higher profit;

- fear of property bubble on an aggressively booming real estate sector. Social concerns relate to both price increases and decreases, which result from government attempts to settle down the economic situation on the housing market. The concerns are heightened by an emerging trend of buying apartments not for sale, but speculation by the so-called residential uncles and aunts. The introduced restriction manifests itself in the fact that a married couple can buy only one apartment. It resulted in the new phenomenon of the

\footnotetext{
${ }^{1}$ Data for 2007 concern 246 countries analyzed by the World Bank, these figures do not include data for Hong Kong.
} 
so-called fake divorces, initiated only to enter another fictitious marriage and acquire a new property. Its consequence was issuance of a new regulation stating that only one year after divorce there is a possibility to buy a new flat. The above has not, however, limited the speculative imagination of the Middle Kingdom's inhabitants. Extremely high housing prices were observed in major Chinese cities, such as: Beijing, Shanghai, Guangzhou and Shenzhen, which are in short called: Bei-Shang-Guang-Shen. For instance, in Beijing, an apartment located inside the fourth northern bypass (the fourth ring) in 2005 was priced at RMB 8 thousand per square meter, and as much as RMB 70 thousand per square meter in 2016. The above bring about two phenomena: formation of vacant buildings and concern over losing investment in real estate, which account for around $70 \%$ of city dwellers' savings, and what stands in opposition the number of people without their lodging, and therefore often lacking access to better schools for their children, connected to the place of residence in a given district;

- aging society - the state deepened by the one child policy pursued between 1977 and 2015. This situation brings about, among others, concerns related to: the necessity of organizing increased health care (including prevention, diagnostics and treatment phase), which would enable prolonging professional activity of elderly people in the future, development of care institutions for the elderly, preparation of infrastructure conveniences, introducing pension insurance system, as well as preparation of present children to take economic responsibility for parents and grandparents in the future;

- no social security system, especially health and pension insurances, which are mainly available on the private market, aimed at more affluent part of the society. Social dissatisfaction also manifests itself in the subject of high quality education and good healthcare. Both of them are mainly available in cities, additionally, more and more of these services are moved to the private sector, which is available to people who can afford it. Another factor is high competitiveness among young people, especially when it comes to stages, such as: high school - the results from maturity exam decide about the possibility of studying in one of the leading academic centers, and then after graduation, when entering the labor market. It not only requires extremely persistent work at the expense of health (related to, among others, overweight and obesity (Determinants and dynamics of the obesity epidemic; Obesity Report for China, p. 12) resulting from sedentary lifestyle, deteriorating visual acuity - the necessity to wear glasses (Sarek)) and loss of childhood charms, but also through enormous ambient pressure, it mentally burdens young people and even other members of their immediate family.

The Chinese side assumed, among others, that, by 2021, China will balance its development, by 2035 , it will become innovative society, whereas by 2049 , which is the $100^{\text {th }}$ anniversary of establishing PRC, there will be a great renaissance of the Chinese nation (Góralczyk, 2018, 364). These are very ambitious plans and a part of them is already under implementation. For instance, as a part of the "energy revolution", the construction of a low-emission economy 
that reduces energy consumption through: restructuring of the coal sector, development of the gas and nuclear sector, as well as innovative "green energy", renewable resources, is manifested in the fact that currently out of 10 wind turbine manufacturers, half of them come from the PRC. Similarly, among solar panels manufacturers, China occupies the second position just after Germany (Gacek). According to Hu An'gang, who referred to Deng Xiaoping's statement from 1962, it is not important whether the cat is black or white, what is important is that the cat catches mice - China in the future will alter from the biggest black cat into the biggest green cat (Hu, 2017, p. 7). The plans also include modernization of metallurgy and other branches of industry to limit generated pollution, they also include work on ecological means of transport, raise of the minimum wage, work on determining optimal income tax and tax deductions related to education and health protection, cooling the real estate market etc. Hu An'gang expresses the opinion that the "black" model of economic development, which was conducted by China and which lasted until the year 2000, was dictated by Western countries, whereas the new "green" model will be their innovative way, not based on imitation, but on inspiring others (mainly the countries of the South). The "green" development is a part of the fourth industrial revolution (the period 2000-2050), during which the economic system will become environmentally friendly and the gap between man and environment will decrease ( $\mathrm{Hu}, 2017$, pp. 46, 50-51, 63). However, the group of international observers is rather skeptical about such ambitious plans of the Chinese government. Disbelief takes place mostly due to not only the present state and scale of needs (manifesting themselves mainly in declarations of concern, not in the active attitude of the citizens), but also, as Łukasz Gacek points out - that despite the possibility to carry out great strategic reforms by the communist party, one can get the impression that any activities, which gain social acceptance, mainly aim at consolidating and increasing political position (Gacek, 2005, p. 245).

\section{Summary}

The cycles established by the forces of nature regulated the lives of the people of Middle Kingdom since ancient times, they lived according to seasons and/or cycles of the Moon (with use of the lunar, solar, yin-yang and nongli calendars) to maintain harmony with nature. They adapted to the rhythm of nature, but also interfered with it by transforming it according to their needs, whereas occurring anomalies in nature - natural disasters - were interpreted as the loss of the mandate of the Heavens by the governing ones. Nowadays, as a result of human interference, the intense production of goods and services, which excessively exploits natural resources has, among others, led to: climate changes, decreasing population of animal species, extinction of flora, erosion and degradation of soil, shortage/pollution of water and air, but also to social disharmony, which is visible, for example, in dissatisfaction caused by social 
stratification, mass migration of people from rural areas to cities, aging society etc. The above facts draw attention to the need of developing necessary tools to create and implement the sustainable development strategy by China. The Chinese side presents the vision of sustainable development, which is possible to achieve already in 2021. It indicates the possibility of transforming China's disharmony into green country (year 2050), which is socially harmonized. Due to both the existing belief that the party can lose support and the mandate of the Heaven, resulting in the disturbance of social order, and the implementation of the green China theory promoted by $\mathrm{Hu}$ An'gang, there might be hope that the situation will improve and green development will ensure re-harmony with nature and social well-being. Nevertheless, compatibility of opinions presented by the Chinese side and people outside of China mainly concerns the statement that harmony between the social, economic and natural systems, protecting biodiversity (Burchard-Dziubińska, 1994) in China, is a socially expected undertaking, nonetheless, long-standing and requiring constant involvement of not only the present, but also future generations.

\section{References}

1. 2018 EPI Results, Yale University. Retrieved from https://epi.envirocenter.yale.edu/epitopline? country=china, 24.02.2019.

2. Brede, N. Dwadzieścia cztery pory roku. Typescript.

3. Burchard-Dziubińska, M. (1994). Wdrażanie koncepcji ekorozwoju przez polskie przedsiębiorstwa przemysłowe, [in:] Wdrażanie polityki ekorozwoju. Kraków: ESES i ZN Oddział Polski.

4. Chi, X-L., Xu, X-T., Yu, T., Liu, Y-N. (2017). Threatened medicinal plants in China: Distributions and conservation priorities. Biological Conservation, 210.

5. China's Population and Development in the 21st Century, Information Office of the State Council of the People's Republic of China, Beijing 2000. Retrieved from http://www.chinaembassy.lt/eng/zt/zfbps/t125259.htm, 22.02.2019.

6. Davies, P.A., Westgate, R.A. (2018). China Faces Serious Water Supply Problems. Retrieved from https://www.globalelr.com/2018/06/china-faces-serious-water-supplyproblems/, 24.02.2019.

7. Determinants and dynamics of the obesity epidemic, CORDIS Komisja Europejska. Retrieved from https://cordis.europa.eu/project/rcn/107381/brief/pl, 15.03.2019.

8. Eberhard, W. (2001). Symbole chińskie. Słownik. Kraków: Universitas.

9. Fu, Z-T., Li, Y-M., Lu, Z-L., Chu, J., Sun, J-D., Zhang, J-Y., Zhang, G-H., Xue, F-Z., Guo, Z-L., Xu, A-Q. Lung cancer mortality clusters in Shandong Province, China: 
how do they change over 40 years? Retrieved from https://www.ncbi.nlm.nih.gov/pmc/ articles/PMC5687644/, 24.02.2019.

10. Gacek, Ł. (2015) Lecture promoting the book Zielona energia w Chinach. Wydawnictwo Uniwersytetu Jagiellońskiego, taking place on the day 15.04.2015 at the Opole University of Technology.

11. Global Wealth Databook 2017 (2017). Research Institute, Credit Suisse.

12. Góralczyk, B. (2018). Wielki renesans. Chińska transformacja i jej konsekwencje. Warszawa: Dialog.

13. Hu, A.G. (2017). Chiny. Innowacyjny zielony rozwój. Wydawnictwo Adam Marszałek.

14. Is air quality in China a social problem? Retrieved from https://chinapower.csis.org/airquality/\#, 24.02.2019.

15. Kajdański, E. (2005). Chiny Leksykon. Warszawa: Książka i Wiedza.

16. Kerol, E. (2018). In search of fluctuations: Another look at China's incredibly stable GDP growth. Retrieved from https:/www.cb.cityu.edu.hk/ef/doc/GRU/GBG\%202018/Eeva\% 20Kerola.pdf, 29.03.2019.

17. Lei, Xiong (2009). Sustainable Development. In: Berkshire Encyclopedia of China. Great Barrington, Massachusetts: Berkshire.

18. Mazur-Kajta, K. (2018). Harmonia w komunikacji o chińskim charakterze - spostrzeżenia z Polskiej (Europejskiej) perspektywy. Zeszyty Naukowe Politechniki Śląskiej, Organizacja i Zarządzanie, z 124. Gliwice: Wydawnictwo Politechniki Śląskiej.

19. Mazur-Kajta, K. Harmonia jak okiem sięgnać. Typescript.

20. Mazur-Kajta, K., Lipińska, P. (2018). Harmonijna komunikacja w opinii młodego pokolenia Chińczyków, [in:] K. Mazur-Kajta (Ed.), Przegląd Nauk Stosowanych, 18/(1), Opole: Politechnika Opolska.

21. Obesity Report for China, Retrieved from http://www.unicef.cn/en/uploadfile/2018/0423/ 20180423114400165.pdf, 15.03.2019.

22. Obringer, F. (2009). Środowisko. In: Leksykon wiedzy o Chinach współczesnych. Warszawa: Dialog.

23. Sarek, K. (2018). Inwazja okularników. Kultura liberalna. Retrieved from https://kulturaliberalna.pl/2018/11/09/chiny-inwazja-okularnikow/, 15.03.2019.

24. Species are disappearing... Retrieved from https://en.wwfchina.org/en/what_we_do/ species/, 24.02.2019.

25. The World Bank. Retrieved from https://data.worldbank.org, 06.04.2019.

26. Webber, M. (2017). Tackling China's water pollution, Global Water Forum. Retrieved from http://www.globalwaterforum.org/2017/10/09/tackling-chinas-water-pollution/, 24.02.2019.

27. WWF: Urbanizacja i uprzemysłowienie Chin zagrażaja bioróżnorodności. Nauka w Polsce, Ministerstwo Nauki i Szkolnictwa Wyższego. Retrieved from http://naukawpolsce.pap.pl/ aktualnosci/news\%2C393342\%2Cwwf-urbanizacja-i-uprzemyslowienie-chin-zagrazajabioroznorodnosci.html, 24.02.2019. 
28. 中华人民共和国 可持续发展国家报告 (Zhōnghuá rénmín gònghéguó kě chíxù fāzhăn guójiā bàogào), China RIO +20. Retrieved from http://workspace.unpan.org/sites/Internet/ Documents/B2CN12\%20\%E5\%8F\%AF\%E6\%8C\%81\%E7\%BB\%AD\%E5\%8F\%91\%E5 $\%$ B1\%95.pdf, 26.02.2019.

29. 中国人的 20 个传统节日, 武世同 (Ed.), 经济科学出版社, 北京 (2011). Zhōngguó rén de 20 gè chuántǒng jiérì, Wǔshìtóng (Ed.), jīngjì kēxué chūbăn shè, běijīng.

30. 中国应对气候变化国家方案 (Zhōngguó yìngduì qìhòu biànhuà guójiā fāng'àn), Embassy of the People/s Republic of China in the United Kingdom of the Great Britain and Northern Ireland. Retrieved from https:/www.fmprc.gov.cn/ce/ceuk/chn/zyxw/ t332707.htm, 24.02.2019.

31. 中国水土流失面积占国土3成每年损失百万亩耕地 (Zhōngguó shǔ̌tǔ liúshī miànjī zhàn guótǔ 3 chéng měinián sǔnshī băi wàn mǔ gēngdi). Retrieved from http://news.163.com/15/ 1103/01/B7F8TP9O00014AEE.html, 24.02.2019.

32. 陈竺，中国每年因空气污染导致早死 35 万-50万人，21世纪经济报道， 07.01.2014. Chen Zhu, Zhōngguó měinián yīn kōngqì wūrăn dăozhì zăosǐ 35 wàn-50 wàn rén, 21 Shìjì jīngjì bàodào, 07.01.2014. 